\title{
ПСИХОЛОГІЧНІ ОСОБЛИВОСТІ ПЕРЕЖИВАННЯ СТРЕСУ У ПІДЛІТКІВ 3 ОКУПОВАНИХ ТЕРИТОРІЙ
}

\author{
УДК: $159.922: 378$
}

\author{
Макаренко Наталя Миколаӥвна \\ кандидат психологічних наук, доиент кафедри \\ загальної та вікової психології Криворізького дер- \\ жавного педагогічного університету, м.Кривий \\ Piг (Україна)
}

\section{Гончарова Тетяна}

студентка психолого-педагогічного факультету (спечіальність «Практична психологія») Криворізького державного педагогічного університету м.Кривий Ріг, (Украӥна)

\begin{abstract}
Анотація. У статті розглядається актуальна проблема украӥнських реалій психологічні особливості переживання стресу підлітками з окупованих територій у порівнянні з їх ровесниками, які проживають на території без бойових дій або мають батьків - учасників АТО. Представлено стислий огляд наукових досліджень щэодо порушень емоційної сфери, фізіологічних, емоиійних, поведінкових проявів стресу. Надані результати поглибленої психодіагностики самопочуття, настрою, активності, пізнавальної активності, мотивачії навчання. Зроблена спроба визначення основних дій практичного психолога у роботі з дітьми, які переживають наслідки стресових, травматичних ситуачій.
\end{abstract}

Ключові слова: підлітковий вік, стресові ситуаиії, емоиійна сфера, посттравматичний синдром, негативний вплив, корекційна робота.

Постановка проблеми. У реаліях порушення мирного врівноваженого життя громадян нашої країни нещодавно з'явилося таке поняття як «посттравматичний синдром», його стресові прояви. За визначенням Вікіпедії: це важкий психічний стан, різновид тривожного розладу, що виникає у результаті одини- чної або повторюваних психотравмуючих ситуацій. При ньому проявляється група характерних симптомів, зокрема стрес, який впливає на фізіологічну, когнітивну, поведінкову сфери життя особистості [1].

Особливо тривожним фактором є те, що посттравматичний стресовий розлад пере- 
живають підлітки, сама специфіка віку яких є проблемною та нестабільною. Для практичних психологів (як працюючих, так і майбутніх) надзвичайно важливо оволодіти знаннями щодо специфіки психотравматичних розладів у дітей та дорослих та засобами подолання їх наслідків. Саме тому, наше дослідження проблеми вважаємо своєчасним та актуальним.

Анализ останних досліджень та публікацій. Питання стресу як наслідку посттравматичних розладів піднімалася у науковій літературі ще за часів «Исследования истерии» 3. Фрейда, де висувалася думка, що корені психічних розладів слід шукати у психологічній травмі. Велика кількість військових конфліктів народила поняття «в’єтнамський», «афганський», «посттравматичний синдром», що активізувало дослідженняцієї проблеми військовими психіатрами. Крім того, питанню приділяли увагу: М. Магомед-Емінов, який виділив реактивну, диспозиційну, інтеракційну моделі, що пояснювали походження постравматичних порушень [3]; А. Меркер, що систематизував умови виникнення посттравматичного стрессу, розладів (захисні, фактори ризику). Г. Каплан надав опис симптомів (переживання, запобігання, підвищена збудливість); Є. Петрова, С. Самсонова, А. Калуєв досліджували шляхи попередження негативних наслідків стрессу у дітей [2;4]; I. Сильонок надала результати досліджень наслідків стресу у підлітковому віці [7].

Досить велике значення приділяється дослідженню такого явища як стрес. У нашу мову слово «стрес» прийшло з англійської мови, а в англійський - 3 латинського. На думку Р. Розенфельда термін «стрес» вперше з'являється в XVIII ст. у фізиці, де він розглядався як характеристика будь-якої напруги, тиску, сили, що прикладається до будь-якої системі (приладу, матеріального об'єкту і т.д.), деформація, що виникла в предметі під впливом цієї сили. Дане поняття терміна «стрес» збереглося у технічних науках і до наших днів $[6,99-$ 101]. Вперше в фізіології і медицині цей термін був використаний в 30-і pp. XX ст. всесвітньо відомим лікарем і біологом Г. Сельє. Терміном «стрес» вчений пропонував позначати неспецифічні реакції організму людини («загальний адаптаційний синдром») у відповідь на несприятливий вплив з3овні [8,52]. Представник Британського психологічного товариства Д. Фонтана, досить ретельно досліджував проблему стресу, відзначаючи що саме слово «стрес» вільно використовується багатьма людьми різних професій. Інженери використовують цей термін при характеристиці допустимих технічних навантажень. Лікарі, застосовуючи цей термін, мають на увазі опис психічних механізмів, станів, пережитих людиною. Психологи (зокрема, Л.Панченко) терміном «стрес» характеризують зміни поведінки людини і т.д. [6, 11-12].

Дещо пізніше в психології, біології, медицині та інших галузях природничонаукового знання термін «стрес» найчастіше використовується в двох значеннях, узагальнення яких представила В. В. Суворова: 
- Під стресом розуміють фізичний, хімічний чи емоційний фактор, який викликає фізіологічну або психологічну напругу і може бути джерелом хвороби.

- Під стресом розуміється і сама хвороба, яка виникає в результаті дії цих факторів.

Таким чином, $з$ одного боку, стрес позначає собою фактор, що впливає на організм, 3 іншого - результат впливу цього фактора [9, 199-201].

Постановка завдання. На наш погляд, потрібно продовжувати дослідження нових аспектів дослідження стресових розладів у підлітковому віці. Зокрема, проводити поглиблену діагностику самопочуття, настрою, активності, пізнавальної активності, мотивації навчання підлітків, які проживають у зоні бойових дій, визначати основне спрямування діяльності практичного психолога у роботі з дітьми, які переживають наслідки стресових, травматичних ситуацій.

Виклад основного матеріалу. Для виявлення особливостей переживання травматичного стресу, нами було сформовано діагностичний комплекс: опитування, спостереження, тестування, зокрема, опитувальник «Самопочуття. Активність. Настрій $(\mathrm{CAH}) »$, розроблений М. Сеченовим, В. А. Доськиним, Н. А. Лаврентьєвим, В. Б. Кулі, М. П. Мірошниковим. Дана методика призначена для оперативної оцінки особливостей психоемоційного стану.

Друга використана методика
«Діагностика мотивації навчання та емоційного ставлення до навчання», заснована на опитувальнику Ч. Д. Спілбергера, яка дозволяє діагностувати мотивацію навчання та емоційного ставлення до нього, вона спрямована на вивчення рівня пізнавальної активності, тривожності і гніву як актуальних станів особистості

Третя - проективна методика «Людина під дощем», орієнтована на діагностику особистісних резервів і особливостей захисних механізмів людини, його здатності долати несприятливі ситуації, протистояти їм, вона також може розповісти про можливості людини до адаптації. При інтерпретації звертається увага на: розмір фігури, відсутність основних деталей, місце фігури на аркуші, використання кольорів, присутність парасольки, калюж, хмар, блискавок тощо.

Вибір означених методик пояснюємо необхідністю комплексного вивчення як емоційної сфери підлітка, так і його мотивації навчання.

Емпіричне дослідження здійснювалось на базі Криворізької загальноосвітньої школи I-III ступенів №85 та на базі комунального закладу Станично-Луганської загальноосвітньої школі I-III ступенів №1 Луганської області. У проведенні діагностичного дослідження допомагала практичний психолог СтаничноЛуганської школи Тимохіна Наталя Геннадіївна. Дослідження проводилось протягом грудня 2015 року - лютого 2016 року. Загальна 
вибірка склала 85 осіб, серед них учні 6-8 клаcy.

Всіх досліджуваних ми розподілили на три групи за такими ознаками:

1) Група 1 (30 осіб)— це контрольна група, до якої увійшли діти, які проживають на мирній території і не були свідками військових дій на сході країни;

2) Група 2 (30 осіб) — це група до якої увійшли діти, які не були свідками військових дій, але чиї батьки знаходилися у зоні АТО. Вони потребують уваги, так як є непрямими свідками цих подій, вони чують про війну, хвилюються про близьких, що захищають Батьківщину, і бачить зміни, які відбуваються 3 ними після повернення додому.

3) Група 3 (25 осіб) - це група до якої увійшли діти, які на даний час знаходяться на окупованих територіях держави.

На рис. 1 представлені зведені профілі якісно-кількісного поєднання показників психоемоційного стану. На осі ОХ відмічені показники психоемоційного стану (за методикою САН), на осі ОУ відмічені їх числові значення, що виражені у балах.

Як ми бачимо - середні показники за трьома шкалами трьох груп майже однакові. Відмінним є показник активності (дещо знижений) у третьої групи досліджуваних. Проте достовірних відмінностей не спостерігається.

За методикою «Діагностика мотивації навчання та емоційного ставлення до навчан- ня», нами були отриманні наступні результати.

У таблиці 1 наведенні данні трьох груп за першою шкалою «Пізнавальна активність».

Як ми бачимо, високий рівень пізнавальної активності серед трьох груп спостеріга-

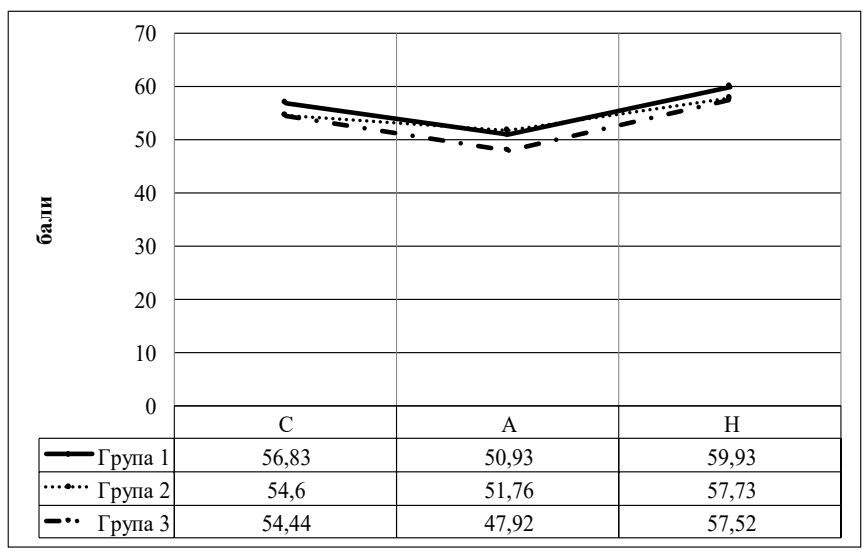

Рис. 1. Профілі психоемоційного стану підлітків*

* Примітка: 1) Група 1 - ие контрольна група, до якої увійшли діти, які проживають на мирній території; група 2 - ие група до якої увійшли діти, які не були свідками військових дій, але чиї батьки знаходилися у зоні АТО. Група 3 - ие група до якої увійшли діти, які на даний час знаходяться на окупованих територіях держави.

2) умовні показники психоемочійного стану: $C$ - самопочуття; $A-$ активність, $H-$ настрій.

ється у досліджуваних першої групи (70\%). У третій групі серед досліджуваних переважає середній рівень пізнавальної активності (52\%), та присутній низький рівень (8\%), якого немає у перших двох групах. В межах другої групи серед досліджуваних переважає високий рівень (66\%) пізнавальної активності.

$$
\text { Щодо показників шкали }
$$

«Тривожності», то за нею спостерігається високий рівень (12\%) у досліджуваних третьої 
групи, хоча в межах групи переважає кількість досліджуваних з середнім рівнем триво-

Таблиия 1

Результати пізнавальної активності підлітків

\begin{tabular}{|c|c|c|c|}
\hline & \multicolumn{3}{|c|}{$\begin{array}{c}\text { Шізналальна активність } \\
\text { Довень прояву) }\end{array}$} \\
& \multicolumn{3}{|c|}{} \\
\cline { 2 - 4 } & Високий & Середній & $\begin{array}{c}\text { Низь- } \\
\text { кий }\end{array}$ \\
\hline Група 1 & $70 \%$ & $30 \%$ & - \\
\hline Група 2 & $66 \%$ & $34 \%$ & - \\
\hline Група 3 & $40 \%$ & $52 \%$ & $8 \%$ \\
\hline
\end{tabular}

жності (60\%).

Високий рівень гніву на відповідній шкалі серед всіх груп також спостерігається у досліджуваних 3-ої групи (28\%), хоча в межах групи переважає кількість досліджуваних 3 низьким (48\%) рівнем гніву. У першій групі переважає низький рівень гніву, він спостерігається у 57\% досліджуваних. У межах другої групи 47\% мають низький рівень прояву гніву.

На рис. 2. представлені зведені профілі показників рівня пізнавальної активності у підлітків. На осі ОХ відмічені показники пізнавальної активності за методикою «Діагностика мотивації навчання та емоційного ставлення до навчання», на осі ОУ відмічені їх числові значення, що виражені у балах.

Як ми бачимо показники групи 1 та групи 2 майже повністю співпали по трьом шкалам, це свідчить про відсутність відмінностей між пізнавальною активністю підлітків, які проживають на мирній території і не були свідками військових дій на сході країни та підлітками, які не були свідками військових дій, але чиї батьки знаходилися у зоні АТО. У третій групі ми бачимо відмінності за показників по шкалі «ПА», «МД», «Т» та «Г» це свідчить про те, що рівень пізнавальної активності та мотивації досягнення досліджуваних групи 3, підлітків які на даний час знаходяться на окупованих територіях держави нижче, ніж у підлітків, які проживають на мирній території і не були свідками військових дій на сході країни та підлітків, які не були свідками військових дій, але чиї батьки знаходилися у

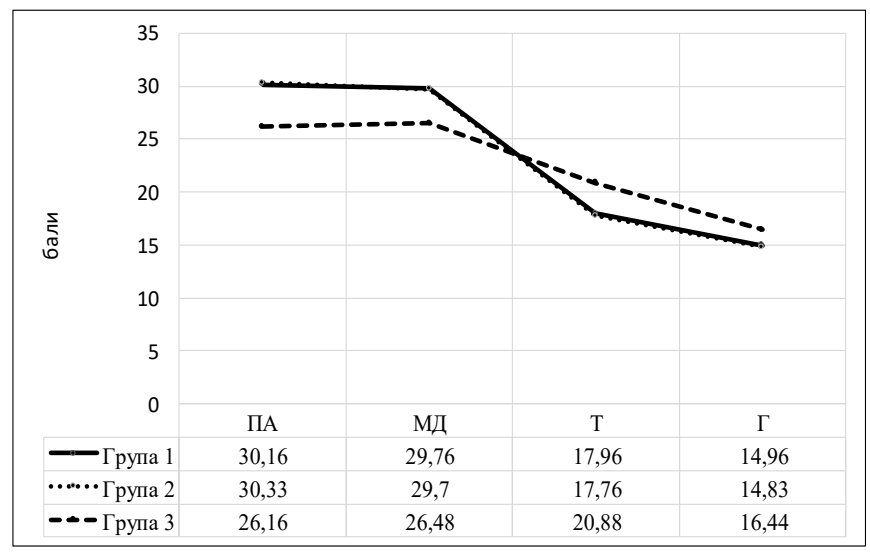

Рис. 2. Профілі пізнавальної активності

\section{підлітків}

Примітка: ПА - пізнавальна активність; МД -мотивачія досягнення; $T$ - тривожність; $\Gamma-$ гнів (агресія).

зоні АТО. Крім того підлітки, які на даний час знаходяться на окупованих територіях держави мають підвищений рівень тривоги та агреciï. 
3 метою встановлення рівня мотивації до навчання трьох груп досліджуваних нами було підраховано загальну кількість балів (див. таблиця 2).

Як ми бачимо, в кожній групі переважає певній рівень мотивації до навчання.

у першій групі переважає 2 рівень (50\%) - це означає, що в дітей продуктивна мотивація, позитивне ставлення до навчання, відповідає соціальному нормативу.

У другій групі найбільш поширений 3 рівень (40\%) - це середній рівень 3 дещо зниженою пізнавальною мотивацією. Повністю відсутній 5 рівень мотивації (0\%), який свідчить про різко негативне ставлення до навчання.

У третій групі дітей переважає 4 рівень (48\%), який свідчить про знижену мотивація, чання і позитивним емоційним ставленням до нього.

Данні за третьою проективною методикою «Людина під дощем» наведенні на рис.3.

Отримані результати дають можливість переконатися у наявності підвищеного рівня негативізму, стриманості емоцій, агресивності, тривожності, втраті орієнтирів досліджуваних третьої групи. Особливо завищеним є показник щодо потреби у захисті, який продемонстрували підлітки з окупованих територій.

Не претендуючи на оригінальність дослідження (отримані результати є досить прогнозовані, передбачувані), ми розуміємо, що основне завдання практичного психолога підвищення уваги до роботи 3 виявленими проблемами. Саме тому нами була розроблена

Таблиия 2

\section{Таблиця результатів рівня мотивації навчання у підлітків}

\begin{tabular}{|c|l|l|l|}
\hline \multirow{2}{*}{ Рівень мотивації до навчання } & \multicolumn{3}{|c|}{ Досліджувані } \\
\cline { 2 - 4 } & Група 1 & Група 2 & Група 3 \\
\hline 1 & $3 \%$ & $7 \%$ & $0 \%$ \\
\hline 2 & $\underline{\mathbf{5 0 \%}}$ & $36 \%$ & $20 \%$ \\
\hline 3 & $34 \%$ & $\underline{\mathbf{4 0 \%}}$ & $28 \%$ \\
\hline 4 & $10 \%$ & $17 \%$ & $\underline{\mathbf{4 8 \%}}$ \\
\hline 5 & $3 \%$ & $0 \%$ & $4 \%$ \\
\hline
\end{tabular}

переживання «шкільної нудьги», негативне авторська програма щодо стабілізації емоційемоційне ставлення до навчання. Відсутність ної сфери підлітків у зонах підвищеного ризи1 рівня свідчить про те, що в групі немає дос- ку, активізація захисних механізмів, підвиліджуваних $з$ продуктивною мотивацією нав- щення мотивації до діяльності. 


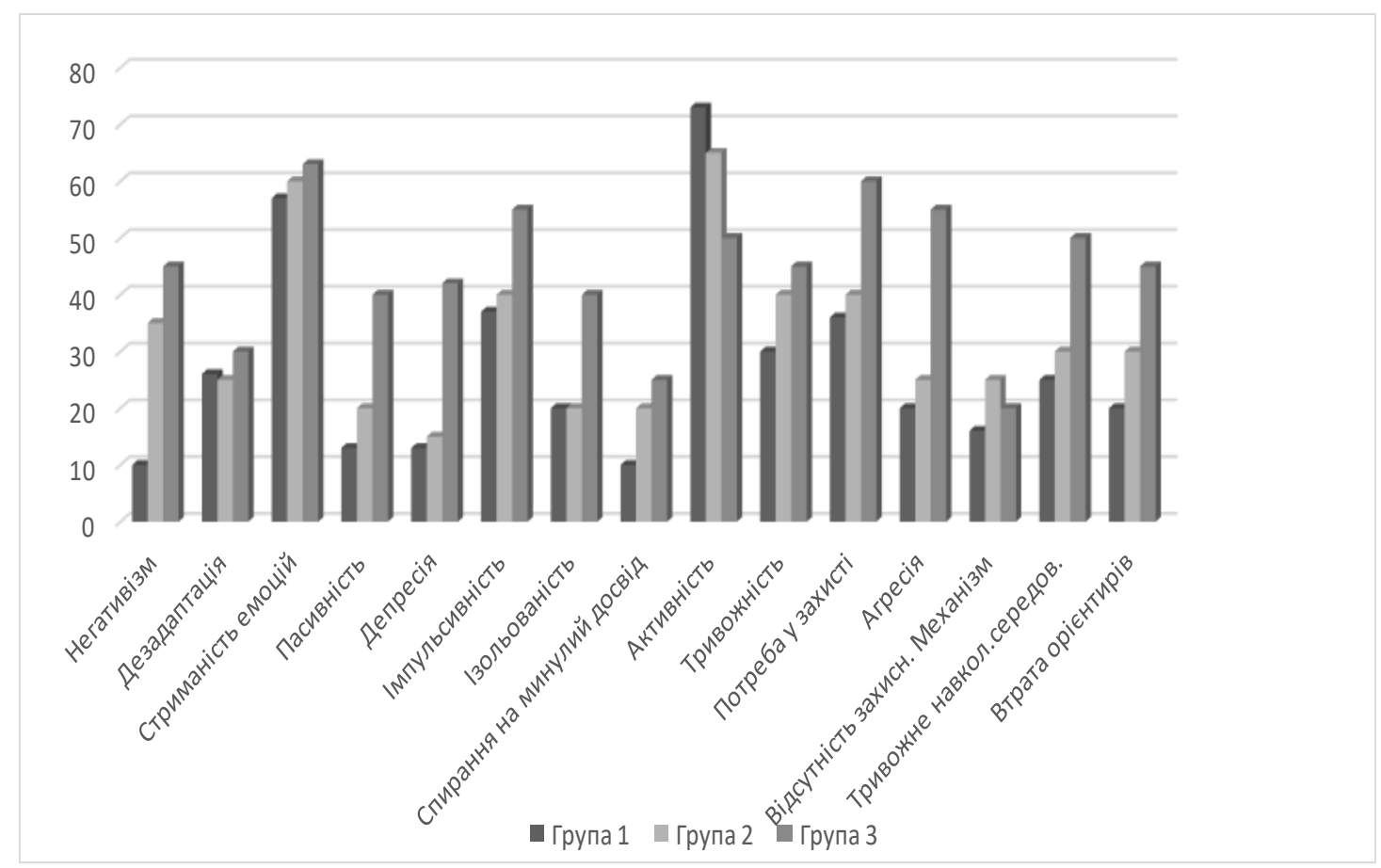

Рис.3. Результати діагностики за методикою «Людина під дощем»

Вона складається з таких розділів:

психоедукачія, яка передбачає теоретичне опрацювання (та впровадження у відповідні аудиторії) різних аспектів проблеми з посиланням на літературні, наукові, медичні джерела (наприклад, знайомство з основними ознаками стресу);

активізація ресурсів, зміна відношення до власного фізичного та психологічного здоров'я, формування здорового способу життя (наприклад, засвоєння основ внутрішньої емоційної ревізії);

соиіальна інтегращзія, яка підсилює процес соціалізації підлітка (наприклад, активізація волонтерської діяльності);

психокорекиія, у процесі якої буде проводитися індивідуальна робота щодо про- філактики зниженої мотивації до навчання, тривожності, агресивності, негативізму, відчуття ізольованості, формування навичок самодопомоги у підлітків, які перебувають на окупованій території.

\section{Висновки та перспективи досліджень}

Посттравматичний стрес, пережитий дитиною, може торкнутися всіх рівнів її функціонування. Стійкі особистісні зміни, що не дають можливості дитині реалізувати себе у майбутньому, різноманітні порушення (психосоматичні, у когнітивній, поведінковій сферах), несформованість соціальних ролей, агресивність сприяють формуванню специфічного життевого сценарію. Його основні наслідки: відсутність контролю над імпульсивністю, зниження здатності до самовира- 
ження, довіри до людей, депресія, страх потребують активного втручання фахівцівпсихологів.

На жаль, обсяги наукової статті не дають можливості більш розгорнуто представити всі результати діагностичної, а особливо експериментальної корекційної роботи (яка знаходиться у стадії упровадження). Завершення експериментальної роботи планується представити у наступних публікаціях.

\section{Перелік використаних джерел:}

\section{1. ВІКІПЕДІЯ. [Електроний ресурс] //Режим доступу:} uk.wikipedia.org/.../

2. Калуев А.В. Проблемы изучения стрессорного поведения / Алан Валерьевич Калуев. - Киев, 1999. $132 \mathrm{c}$.

3. Магомед-Эминов М.Ш. Личность и экстремальная жизненная ситуация //М.Ш.Эминов. - Вестник Московского университета, 1996. - №4. - С.47-61.

4. Петрова Е.Ю. Как предупредить негативные последствия стресса у детей //Е.Ю.Петрова, Е.В.Самсонова. Москва: Академия, 2010. - С.11-15.

5. Підлипна Л. Посттравматичний синдром [Електроний ресурс] //Режим доступу: http:// www.galychyna.if.ua/publication/prosti-olivci-dljapershoklasnikiv/

6. Панченко Л.Л. Диагностика стресса: [учебное пособие] / Людмила Леонидовна Панченко. - Владивосток: Мор. гос. ун-т, 2005. - 35c.

7. Силёнок И.К. Директор Центра психологии и бизнес консультирования «Логос», г. Краснодар; E-mail: psilenok@mail.ru Характеристика посттравматического синдрома подростков

8.Селье Г. Стресс без дистресса / Ганс Селье; [пер. с англ. А.Н. Лука и И.С. Хорола ]. - М.: Прогресс, 1979.
$-124 \mathrm{c}$.

9.Суворова В.В. Психофизиология стресса / Валентина Васильевна Суворова. - М.: Педагогика, 1975. — 208c.

\section{References (Transliteration):}

1. VIKIPEDIIa. [Elektronyi resurs]//Rezhym dostupu: uk.wikipedia.org/.../

2. Kaluev A.V. Problemы yzuchenyia stressornoho povedenyia / Alan Valerevych Kaluev. - Kyev, 1999. — 132s.

3.Mahomed-Эmynov M.Sh. Lychnost y эkstremalnaia zhyznennaia sytuatsyia //M.Sh.Эmynov. - Vestnyk Moskovskoho unyversyteta, 1996. - №4. - S.47-61.

4. Petrova E.Iu. Kak predupredyt nehatyvnыe posledstvyia stressa u detei //E.Iu.Petrova, E.V.Samsonova. - Moskva: Akademyia, 2010. - S.11-15.

5. Pidlypna L. Posttravmatychnyi syndrom [Elektronyi resurs] //Rezhym dostupu: http://www.galychyna.if.ua/ publication/prosti-olivci-dlja-pershoklasnikiv/

6. Panchenko L. L. Dyahnostyka stressa: [uchebnoe posobye] / Liudmyla Leonydovna Panchenko. - Vladyvostok: Mor. hos. un-t, 2005. - 35s.

7. Sylënok $Y$. K. Dyrektor Tsentra psykholohyy y byznes konsultyrovanyia «Lohos», h. Krasnodar; E-mail: psilenok@mail.ru Kharakterystyka posttravmatycheskoho syndroma podrostkov

8. Sele H. Stress bez dystressa / Hans Sele; [per. s anhl. A.N. Luka y Y.S. Khorola ]. — M.: Prohress, 1979. — $124 \mathrm{~s}$.

9. Suvorova V. V. Psykhofyzyolohyia stressa / Valentyna Vasylevna Suvorova. — M.: Pedahohyka, 1975. — 208s.

\section{Makarenko Natalia}

PhD of psychological sciences, assistant professor of general psychology at the Krivoy Rog State Pedagogical University, Krivoy Rog (Ukraine)

\section{Goncharova Tatiana}

Master student at Krivoy Rog State Pedagogical University, Krivoy Rog (Ukraine) 
PSYCHOLOGICAL PECULIARITIES OF STRESS EXPERIENCE AMONG ADOLESCENTS FROM THE OCCUPIED TERRITORIES

\section{ABSTRACT}

The events in the east of our country greatly affect not only political and economic, but also human factors. The problem of how such events influence the adolescents is especially relevant. The focus of our research is on psychological peculiarities of stress experience and manifestation of post-traumatic syndrome among adolescents living on the occupied territories in comparison with their peers from the territory of peace or those who have fathers-participants of AntiTerrorist Operation. Post-traumatic syndrome is a serious psychological condition displaying a group of specific symptoms (stress) that influences physiological, cognitive and motivational spheres of human life. To diagnose timely and to correct this condition is a major task of practical psychologist.

The diagnostic research showed, as we expected, an increased level of negativism, restraint of positive emotions, aggressiveness as well as high level of anxiety and loss of life guidance among the studied adolescents living in war conflict area. That's why it became necessary to introduce an author's program, elaborated to stabilize the emotional sphere of adolescents in highrisk areas, revitalize protective mechanisms and improve motives for action. The program consists of four units: psychoeducation (theoretical education of the researched); stage of resources revitali- zation (exploitation of internal emotional audit basis); stage of social integration and correcting measures.

Key words: adolescence, stress situations, emotional sphere, post-traumatic syndrome, negative influence, correcting measures.

\section{Макаренко Наталья Николаевна}

Кандидат психологических наук, дочент кафедры общей и возрастной психологии Криворожский государственного педагогического университета, г. Кривой Рог (Украина)

\section{Гончарова Татьяна}

Студент психолого-педагогического факультета Криворожского государственного педагогического университета, г. Кривой Рог (Украина)

\section{ПСИХОЛОГИЧЕСКИЕ ОСОБЕННОСТИ ПЕРЕЖИВАНИЯ СТРЕССА У ПОДРОСТКОВ С ОККУПИРОВАННЫХ ТЕРРИТОРИЙ}

Аннотация. События на востоке нашей страны существенно влияют не только на политические, экономические, но и на человеческие факторы. Особенно актуальна проблема влияния подобных событий на детейподростков. Психологические особенности переживания стресса, проявления посттравматического синдрома у подростков, проживающих на оккупированных территориях в сравнении с их ровесниками с мирных территорий или имеющих отцов-участников АТО - в центре нашего исследования. Посттравматический синдром - это тяжелое психическое состояние, при котором проявляется группа 
характерных симптомов (стресс), влияющий на физиологическую, когнитивную, мотивационную сферы жизни человека. Своевременная его диагностика и коррекция - основная задача практического психолога.

Проведенное диагностическое исследование ожидаемо продемонстрировало наличие повышенного уровня негативизма, сдержанности позитивных эмоций, агрессивности, высокий уровень тревожности, потерю жизненных ориентиров у исследованных подростков, проживающих в зоне боевых действий. Потому возникла необходимость разработки и внедрения авторской программы стабилизации эмоциональной сферы подростков в зоне повышенного риска, активизации защитных механизмов, повышения мотивации к действиям. Программа состояла из четырех блоков: психоэдукации (теоретического просвещения исследуемых); этапа активизации ресурсов (освоения основ внутренней эмоциональной ревизии); этапа социальной интеграции и коррекционной работы.

Ключевые слова: подростковый возраст, стрессовые ситуации, эмоциональная сфера, посттравматический синдром, негативное влияние, коррекционная работа. 